Supporting Information

\title{
Microfluidic, One-batch Synthesis of Pd Nanocrystals on N-doped Carbon in Surfactant-free Deep Eutectic Solvents for Formic Acid Electrochemical \\ Oxidation
}

Hong Zhang, ${ }^{\mathrm{a}, \mathrm{b}} \mathrm{Ke} \mathrm{Lu},{ }^{\mathrm{b}}$ Bomin Li, ${ }^{\mathrm{b}, \mathrm{c}}$ Yuzi Liu, ${ }^{\mathrm{d}}$ Yuanhai Su, ${ }^{\mathrm{a},}$, Rongyue Wang, ${ }^{\mathrm{c}}$ Yingwen Cheng ${ }^{\mathrm{b}, *}$

a School of Chemistry and Chemical Engineering, Shanghai Jiao Tong University, Shanghai, 200240, China.

${ }^{\mathrm{b}}$ Department of Chemistry and Biochemistry, Northern Illinois University, DeKalb, IL 60115, United States.

c Applied Materials Division, Argonne National Laboratory, Lemont, IL 60439 United States

d Center for Nanoscale Materials, Argonne National Laboratory, Lemont, IL 60439 United States

*E-mail: ycheng@niu.edu (Y.C.) and y.su@,sjtu.edu.cn (Y.S.) 


\section{Experimental details}

\section{List of chemicals}

Choline chloride (ACROS Organics, 99\%), XC-72r carbon black (Fuel Cell Stores), ethylene glycol (ACROS Organics, 99+\% extra pure), potassium tetrachloropalladate (Sigma-Aldrich, 99.99\%), Nafion solution (5\%, Sigma-Aldrich), isopropyl alcohol (ACROS Organics, ACS reagent). Pyrrole (ACROS Organics, 99\% extra pure), $\mathrm{FeCl}_{3} 6 \mathrm{H}_{2} \mathrm{O}$ (Sigma-Aldrich, 97\%), hydrochloride acid (Fisher Chemical, certified ACS Plus), commercial Pd/C (10 wt\% Pd loading, Sigma).

\section{Synthesis of nitrogen doped porous carbon support}

The N-carbon porous support was prepared by pyrolysis of polypyrrole at $1000{ }^{\circ} \mathrm{C}$ for $2 \mathrm{~h}$ under Ar flow $(100 \mathrm{sccm})$. The polypyrrole was prepared using a procedure explained in our previous work. ${ }^{1}$ Typically, two precursor solutions were prepared. The first solution contained $1.0 \mathrm{ml}$ pyrrole monomer in $50 \mathrm{ml} 0.5 \mathrm{M} \mathrm{HCl}$ and the second solution contained $0.5 \mathrm{~g} \mathrm{FeCl}_{3}$ in $20 \mathrm{ml}$ water. While under vigorous stirring in ice batch, these two solutions were mixed by dropwise addition of the second solution to the first solution. During this process $\mathrm{Fe}^{3+}$ initiated the chemical oxidative polymerization of pyrrole and resulted in formation of polypyrrole (PPy). The suspension was continuously stirred for 4 hours to ensure completion of polymerization. The obtained polypyrrole was first washed with $0.1 \mathrm{M} \mathrm{HCl}$ and then several times with ethanol and water, and was freeze-dried prior to pyrolysis. After pyrolysis, the obtained carbon was first washed in $0.5 \mathrm{M} \mathrm{H}_{2} \mathrm{SO}_{4}$ for 12 hours, followed by repeated wash via ethanol and water, to dissolve residue Fe species.

\section{Synthesis of Pd NPs in flask reactors}

Synthesis of Pd NPs in DES: the synthesis solution was prepared by dissolving $\mathrm{K}_{2} \mathrm{PdCl}_{4}$ in ChCl-EG DES with a concentration of $7.42 \mathrm{mM} .10 \mathrm{ml}$ solution was added to a flask, which was placed on a hotplate and stirred at $500 \mathrm{rpm}$. The solution was heated from room temperature to $180^{\circ} \mathrm{C}$, and maintained at $180^{\circ} \mathrm{C}$ for $6 \mathrm{~min}$. Afterwards the solution was cooled naturally to room temperature, and washed with a procedure that is the same as microfluidic synthesis.

Synthesis of Pd NPs in pure ethylene glycol: the synthesis was prepared by dissolving $\mathrm{K}_{2} \mathrm{PdCl}_{4}$ in ethylene glycol with a concentration of $7.42 \mathrm{mM} .10 \mathrm{ml}$ of the synthesis solution was 
transferred to a $50 \mathrm{ml}$ round bottom flask equipped with a condenser. The synthesis and postsynthesis treatment procedures were identical as in DES.

\section{Materials Characterization}

Powder X-ray diffraction analysis was performed using a Rigaku Miniflex diffractometer operating at $30 \mathrm{kV}$ and $15 \mathrm{~mA}$ using $\mathrm{Cu} \mathrm{K \alpha}$ radiation $(\lambda=1.5406 \AA)$. TEM images were acquired using a JEOL JEM-2100F microscope at $200 \mathrm{KV}$. The Pd ions concentration was quantified using a UV-Vis spectrometer. The specific surface area and pore size distribution were analyzed using a Micromeritics Tristar 3000 analyzer. The XPS spectra were collected using a Thermal Escalab 250X-ray photoelectron spectrometer (VG Scientifics). The binding energies were calibrated by assigning the $\mathrm{C} 1 \mathrm{~s}$ peak at $284.5 \mathrm{eV}$.

\section{Electrochemical Studies}

All electrochemical tests were performed at room temperature using a Pine Bipotentiostat Electrochemical Workstation and a standard three-electrode configuration. A saturated calomel electrode was used as the reference electrode (SCE) and a graphite rod was used as the counter electrode. The electrolyte was $50 \mathrm{ml} 0.1 \mathrm{M} \mathrm{HClO}_{4}$. The catalyst ink was prepared by mixing $2.0 \mathrm{mg}$ catalysts with $1 \mathrm{ml}$ water/isopropanol mixed solvent $(1: 3 \mathrm{v} / \mathrm{v})$ and $10 \mu 15 \mathrm{wt} \%$ Nafion solution, and was sonicated for at least $30 \mathrm{~min}$ prior to each use. To prepare the working electrode, $8 \mu$ of the catalyst ink was drop-casted onto a glassy carbon disk electrode $(0.196$ $\mathrm{cm}^{2}$ ). The working electrode containing the catalysts was activated by cycling from 0 to $1.2 \mathrm{~V}$ (vs. RHE) at $100 \mathrm{mV} / \mathrm{s}$ until the voltammogram stabilizes. The $\mathrm{CV}$ was obtained from 0.02 to 1.2 V (vs. RHE) in the Ar-saturated $0.1 \mathrm{M} \mathrm{HClO}_{4}$ with a scan rate of $50 \mathrm{mV} / \mathrm{s}$. The formic acid oxidation experiments were performed in Ar-saturated $0.1 \mathrm{M} \mathrm{HClO}_{4}$ electrolyte containing 0.1 $\mathrm{M} \mathrm{HCOOH}$. The $\mathrm{CV}$ was acquired at $50 \mathrm{mV} / \mathrm{s}$ and the chronoamperometry (CA) was carried out at the constant potential of $0.40 \mathrm{~V}$ (vs. RHE) for $2400 \mathrm{~s}$. 


\section{Supplemental calculations}

\section{Reynolds number (Re)}

The Reynolds number was determined using the following equation:

$$
\operatorname{Re}=\frac{\rho v d}{\mu}
$$

where $\rho$ is the density of DES $\left(1.130 \mathrm{~g} / \mathrm{cm}^{3} @ 293 \mathrm{~K}, 1.03 \mathrm{~g} / \mathrm{cm}^{3} @ 453 \mathrm{~K}\right),{ }^{2} v$ is the linear flow velocity, $d$ is the inert diameter of the PFA tube, and $\mu$ is the dynamic viscosity of the fluid (40 mPa·s@293K, $2.086 \mathrm{mPa} \cdot \mathrm{s} @ 453 \mathrm{~K}) .{ }^{2}$

Prandtl number (Pr) can be calculated using the following equation ${ }^{3}$ :

$$
\operatorname{Pr}=\frac{C_{p} \times \mu}{k_{\mathrm{f}}}
$$

where $C_{\mathrm{p}}$ is the specific heat for ChCl-EG DES $(168 \mathrm{~J} / \mathrm{K} \cdot \mathrm{mol}),{ }^{4} k_{\mathrm{f}}$ is the thermal conductivity of ChCl-EG DES and the value of $k_{\mathrm{f}}$ is $0.195 \mathrm{~W} / \mathrm{m} \cdot \mathrm{K} .^{5}$

Nusselt numbers $(\mathrm{Nu})$ can be calculated using the following equations ${ }^{6}$. The $\mathrm{Nu}_{1}$ and $\mathrm{Nu}_{2}$ refer to the Nusselt number of heating zone and cooling zone, respectively.

$$
\begin{aligned}
& \mathrm{Nu}_{1}=\left[\left(3.657+\frac{4.343}{\left(1+\frac{957}{\operatorname{Pr} \times H e^{2}}\right)^{2}}\right)^{3}+1.158 \times\left(\frac{H e}{\left(1+\frac{0.477}{\operatorname{Pr}}\right)}\right)^{3 / 2}\right]^{1 / 3} \\
& H \mathrm{e}==R \mathrm{e}\left(\frac{r}{R_{c}}\right)^{1 / 2}, R_{\mathrm{c}}=R\left(1+\frac{L_{h}}{2 \pi R}\right) \\
& \mathrm{Nu}_{2}=3.66\left(\operatorname{Re} \cdot \operatorname{Pr} \cdot \frac{d_{h}}{L_{c}} \leq 20\right)
\end{aligned}
$$

where $r$ is the radius of the PFA tube, and $R_{\mathrm{c}}$ is the critical radius of the helical coil that is obtained by the radius of the helical $(R)$ and the length of the PFA microchannel in heating zone $\left(L_{\mathrm{h}}\right), L_{\mathrm{c}}$ is the length of cooling zone, $d_{\mathrm{h}}$ is the hydraulic diameter of the PFA tube.

Heat transfer coefficient $(h)$ is given by the following:

$$
\text { Heating zone: } \quad h_{H}=\frac{k_{\mathrm{f}} \times N u_{1}}{d_{\mathrm{h}}} \quad \text { Cooling zone: } \quad h_{C}=\frac{k_{\mathrm{f}} \times N u_{2}}{d_{\mathrm{h}}}
$$

Based on the energy balance, the relationship of temperature and heat transfer coefficient can be expressed by the following equation: 


$$
\frac{T_{L}-T_{I}}{T_{F}-T_{L}}=\frac{\pi \times d_{\mathrm{h}} \times h \times L}{Q \times \rho \times C_{p}}
$$

where $T_{\mathrm{I}}$ is the fluid temperature at the fluid inlet $\left(20^{\circ} \mathrm{C}\right) ; T_{\mathrm{F}}$ is the constant temperature of the PFA channel wall $\left(180^{\circ} \mathrm{C}\right), \mathrm{T}_{\mathrm{L}}$ is the temperature at a given position along the length of the PFA microchannel, $Q$ is the volumetric flow rate of fluid.

\section{Supplemental Figures}
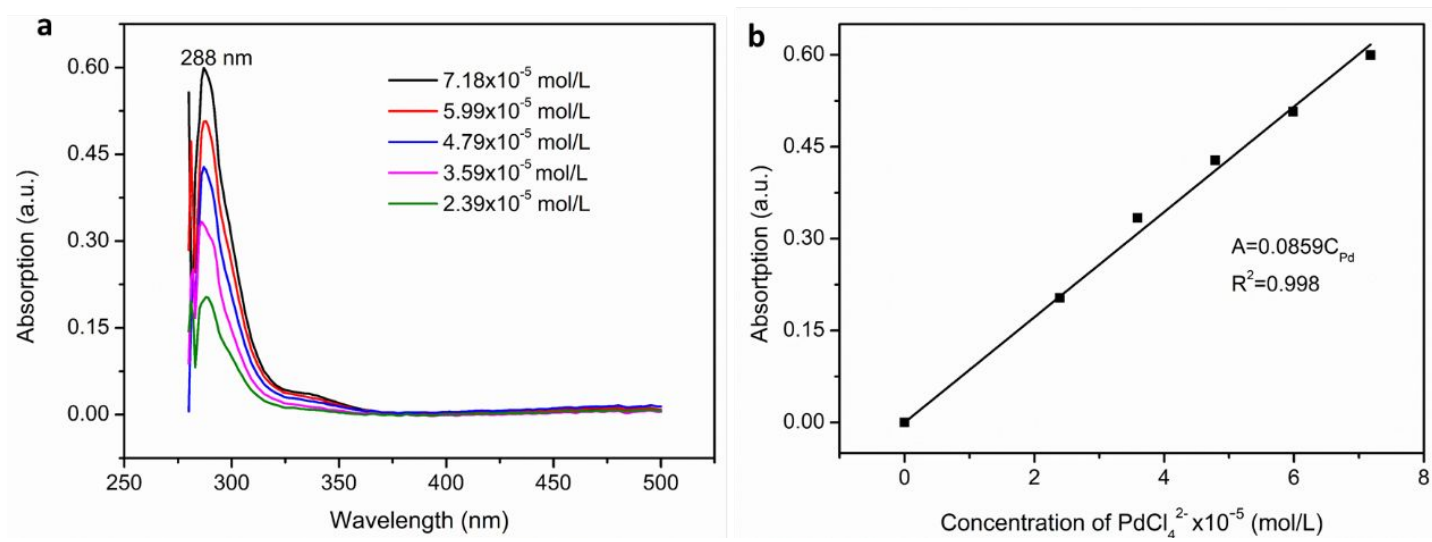

Figure S1. The calibration curve for quantifying Pd-ions concentrations using absorption spectrometry: a) UV-Vis absorption spectra of standard Pd-ion solutions with concentrations noted. The $\mathrm{PdCl}_{4}{ }^{2-}$ anion has a characteristic absorption peak at $288 \mathrm{~nm}$. b) the linear Beer absorption- concentration relationships determined from a).

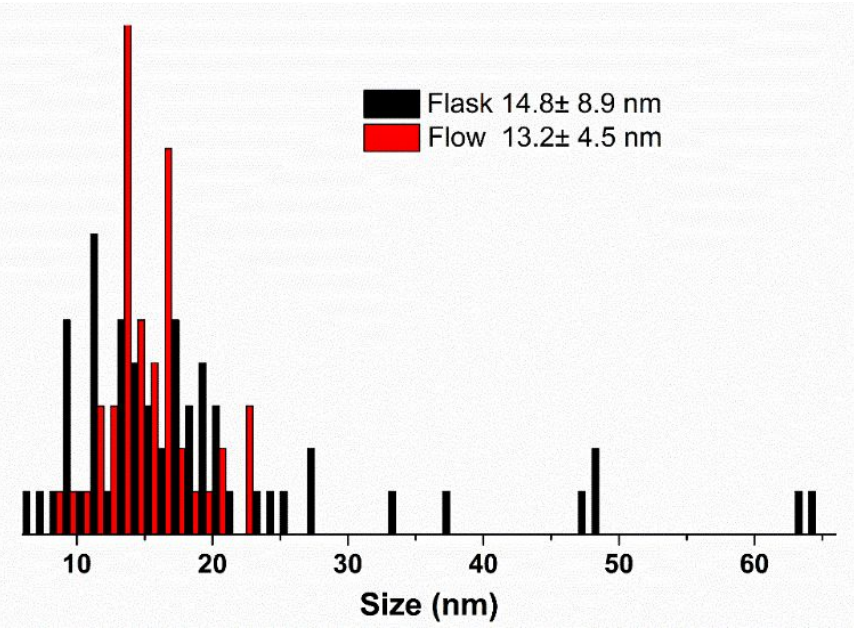

Figure S2. The size distribution of Pd NPs synthesis in flask and microfluidic reactor. 

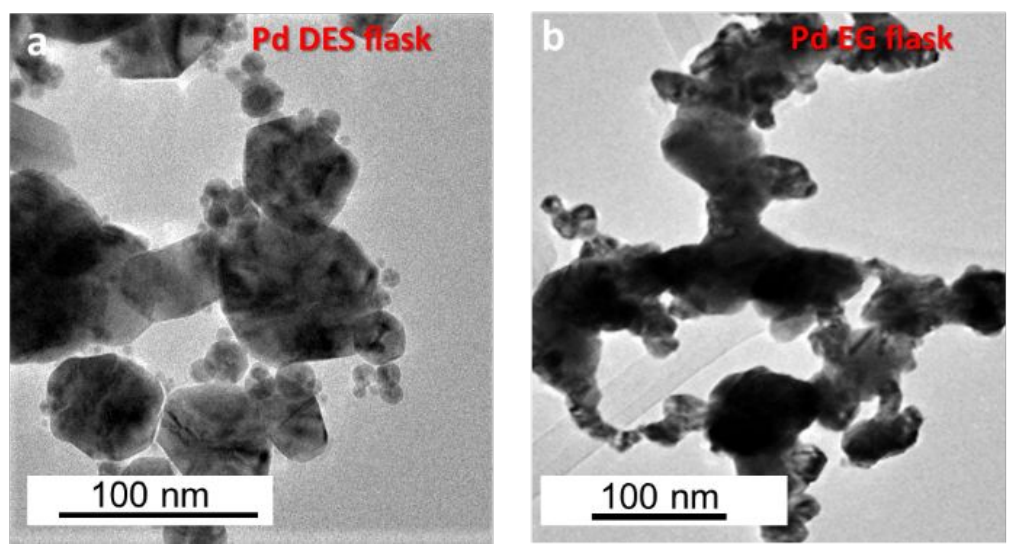

Figure S3. TEM images of Pd particles synthesized in flask reactors at $180^{\circ} \mathrm{C}$ using a) DES and $b$ ) pure EG as the solvent.
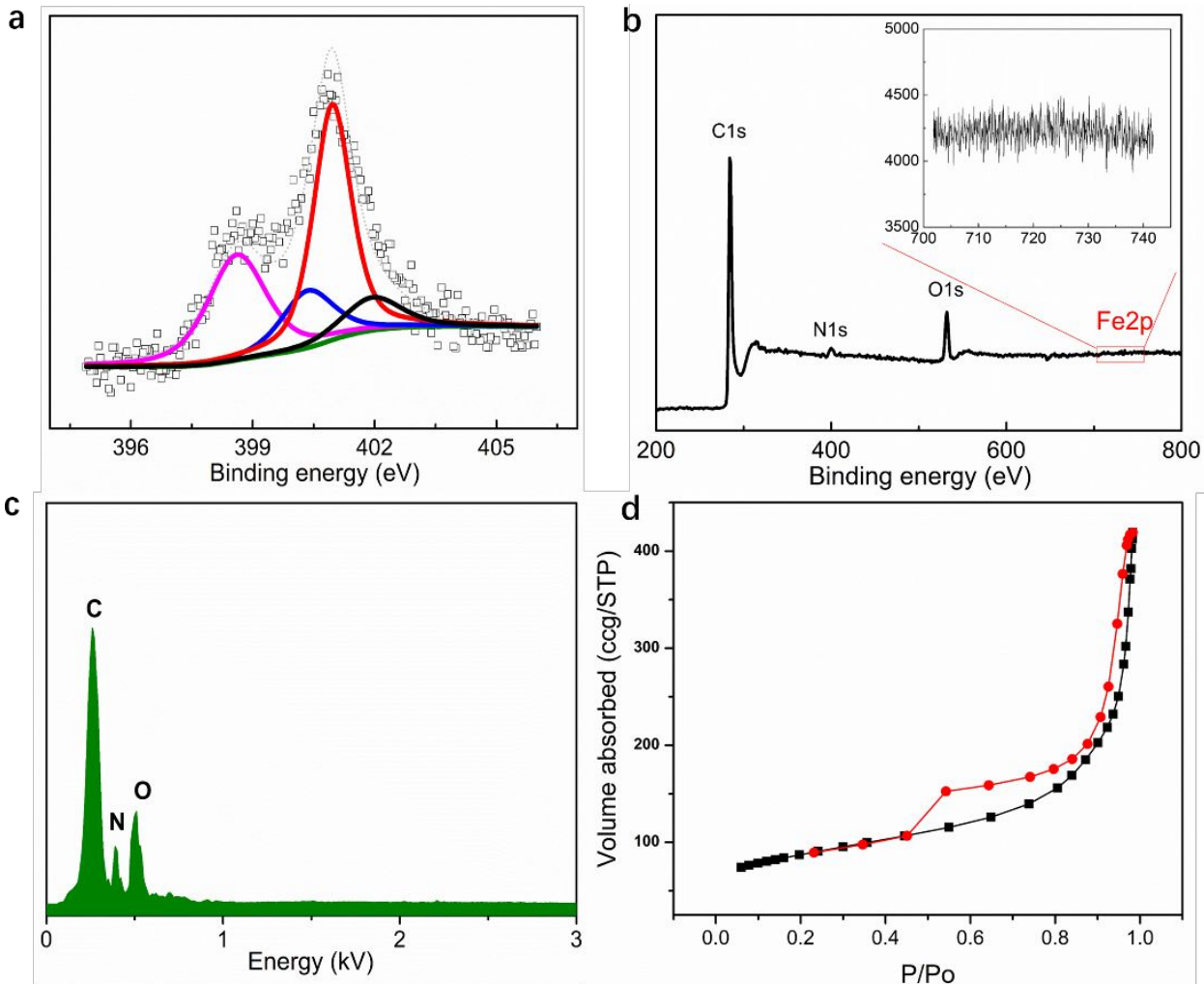

Figure S4: characterization results of the mesoporous N-carbon support including XPS $(a, b)$, $\operatorname{EDX}(\mathrm{c})$ and BET (d). 


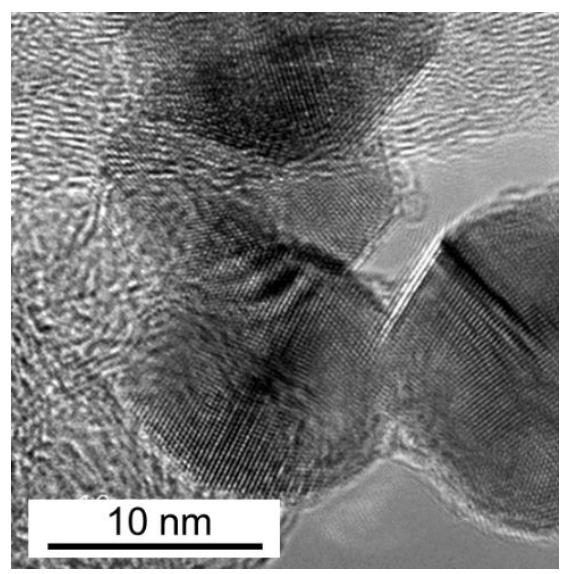

Figure S5. TEM image of Pd NCs for Pd@N-carbon.
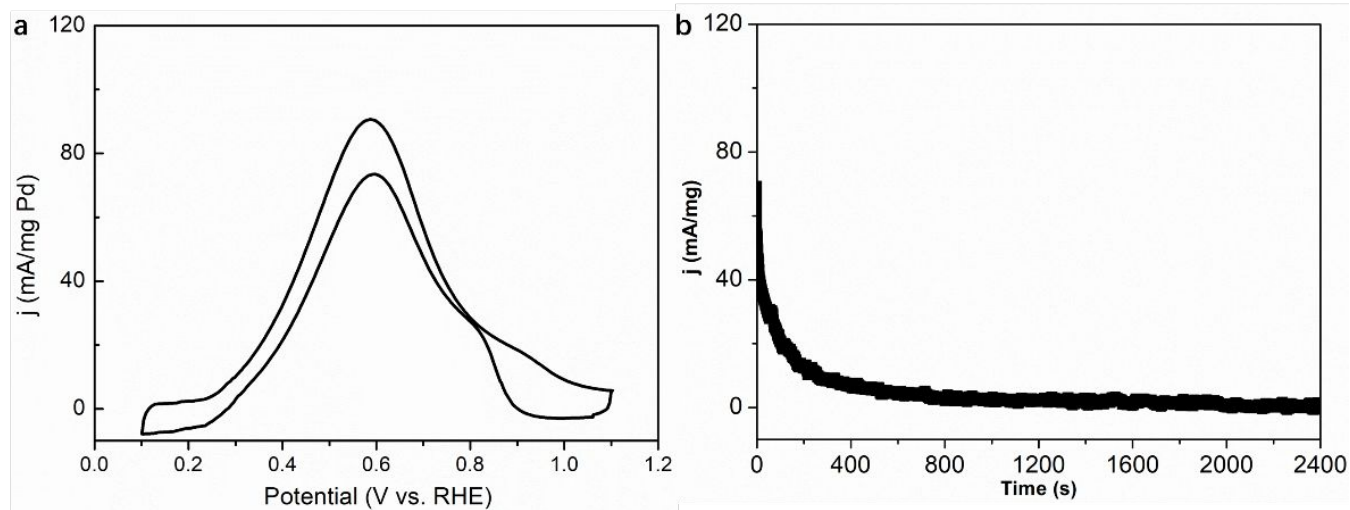

Figure S6. Electrochemical performance of commercial $\mathrm{Pd}(10 \mathrm{wt} \%) / \mathrm{C}$, a) the mass activity for formic acid oxidation, the scan rate was $50 \mathrm{mV} / \mathrm{s}$; b) Chronoamperometry for $2400 \mathrm{~s}$ at $0.5 \mathrm{~V}$ vs. RHE. The electrolyte was $0.1 \mathrm{M} \mathrm{HClO}_{4}+0.1 \mathrm{M}$ formic acid. 
Table S1: comparison of Pd-based catalysts for FAOR with the reported literatures

\begin{tabular}{|c|c|c|c|c|}
\hline Pd-based Catalyst & Synthetic method & Electrolyte & $\begin{array}{l}\text { Mass current } \\
\text { density } \\
(\mathrm{mA} / \mathrm{mg})\end{array}$ & Reference \\
\hline $\begin{array}{l}\text { Pd } @ \text { N-doped } \\
\text { carbon }\end{array}$ & $\begin{array}{l}\text { The mixture solution (DES, N-doped carbon, } \\
\mathrm{K}_{2} \mathrm{PdCl}_{4} \text { ) was heated at } 180^{\circ} \mathrm{C} \text { for } 6 \mathrm{~min} \text { in } \\
\text { microreactors }\end{array}$ & $\begin{array}{l}0.1 \mathrm{M} \mathrm{HClO}_{4}+ \\
0.1 \mathrm{M} \mathrm{HCOOH}\end{array}$ & 362 & This work \\
\hline Pd @XC-72 & $\begin{array}{c}\text { The mixture solution (DES, } \mathrm{XC}-72, \mathrm{~K}_{2} \mathrm{PdCl}_{4} \text { ) was } \\
\text { heated at } 180^{\circ} \mathrm{C} \text { for } 6 \mathrm{~min} \text { in microreactors }\end{array}$ & $\begin{array}{l}0.1 \mathrm{M} \mathrm{HClO}_{4}+ \\
0.1 \mathrm{M} \mathrm{HCOOH}\end{array}$ & 210 & This work \\
\hline Pd/DNA@graphene & $\begin{array}{l}\text { The mixture }\left(\mathrm{PdCl}_{2}, \mathrm{DNA} @ \text { graphene and ethylene }\right. \\
\text { glycol) was treated by refluxing at } 160^{\circ} \mathrm{C} \text { for } 4 \mathrm{~h}\end{array}$ & $\begin{array}{l}0.5 \mathrm{M} \mathrm{H}_{2} \mathrm{SO}_{4}+ \\
0.5 \mathrm{M} \mathrm{HCOOH}\end{array}$ & 140.1 & [7] \\
\hline Pd/Graphene & $\begin{array}{c}\text { The reaction mixture }\left(\mathrm{K}_{2} \mathrm{PdCl}_{4} \text {, graphene and ethylene }\right. \\
\text { glycol) reacted at } 120^{\circ} \mathrm{C} \text { for } 15 \mathrm{~h} \text { in Teflon-lined } \\
\text { stainless steel autoclave }\end{array}$ & $\begin{array}{l}0.5 \mathrm{M} \mathrm{H}_{2} \mathrm{SO}_{4}+ \\
0.5 \mathrm{M} \mathrm{HCOOH}\end{array}$ & 247.3 & [8] \\
\hline $\mathrm{Pd} / \mathrm{CNF}$ & $\begin{array}{l}\text { The solution }\left(\mathrm{PdCl}_{2} \text {, trisodium citrate, } \mathrm{NaOH}\right) \text { was } \\
\text { added dropwise to a stirred CNF slurry. After } 2 \mathrm{~h} \text { of } \\
\text { stirring, ice-cold sodium borohydride solution was } \\
\text { added and stirred for additional } 3 \mathrm{~h} \text { at } 10^{\circ} \mathrm{C}\end{array}$ & $\begin{array}{c}0.5 \mathrm{M} \mathrm{HCOOH}+ \\
0.5 \mathrm{M} \mathrm{H}_{2} \mathrm{SO}_{4}\end{array}$ & 730 & [9] \\
\hline Pd tetrahedra & $\begin{array}{l}\text { The homogeneous solution (L-proline, } \mathrm{PVP}, \mathrm{K}_{2} \mathrm{PdCl}_{4} \text {, } \\
\mathrm{HCHO} \text { ) was transferred to a Teflon-lined stainless steel } \\
\text { autoclave and heated at } 140{ }^{\circ} \mathrm{C} \text { for } 4 \mathrm{~h}\end{array}$ & $\begin{array}{c}0.5 \mathrm{M} \mathrm{HCOOH}+ \\
0.5 \mathrm{M} \mathrm{H}_{2} \mathrm{SO}_{4}\end{array}$ & 259.2 & {$[10]$} \\
\hline Pd tetrahedra & $\begin{array}{c}\text { The homogeneous mixture }\left(\operatorname{Pd}(\mathrm{acac})_{2},\left(\mathrm{Fe}(\mathrm{acac})_{2}, \mathrm{PVP},\right.\right. \\
\text { DMF) was heated at } 120^{\circ} \mathrm{C} \text { for } 10 \mathrm{~h} \text { in an oven }\end{array}$ & $\begin{array}{l}0.1 \mathrm{M} \mathrm{HClO}_{4}+ \\
0.2 \mathrm{M} \mathrm{HCOOH}\end{array}$ & 237.6 & [11] \\
\hline Pd network & $\begin{array}{l}\text { The resulting cyanogel }\left(\mathrm{K}_{2} \mathrm{PdCl}_{4} / \mathrm{K}_{4} \mathrm{Fe}(\mathrm{CN})_{6}, \mathrm{NaBH}_{4}\right) \\
\text { was allowed to stand for } 1 \mathrm{~h}\end{array}$ & $\begin{array}{c}0.5 \mathrm{M} \mathrm{HCOOH}+ \\
0.5 \mathrm{M} \mathrm{H}_{2} \mathrm{SO}_{4}\end{array}$ & 280.6 & {$[12]$} \\
\hline Pd/phen-MWCNTs & $\begin{array}{l}\mathrm{KBH}_{4} \text { solution was added dropwise into the solution } \\
(\mathrm{PdCl} 2 \text {, phen-MWCNTs, } \mathrm{NaOH}) \text { under stirring for } 2 \mathrm{~h} \text {, } \\
\text { and then the stirring was continued for } 10 \mathrm{~h} \text { for the } \\
\text { completely reduction of } \mathrm{Pd}^{2+}\end{array}$ & $\begin{array}{r}0.5 \mathrm{M} \mathrm{H}_{2} \mathrm{SO}_{4}+ \\
1 \mathrm{M} \mathrm{HCOOH}\end{array}$ & 222.8 & [13] \\
\hline Pd dendrites & $\begin{array}{l}\text { The mixture }\left(\mathrm{CTAB} \text {, ascorbic acid, } \mathrm{Na}_{2} \mathrm{PdCl}_{4}, \mathrm{Ni}(\mathrm{Ac})_{2}\right) \\
\text { was left undisturbed for } 2 \mathrm{~h} \text { in the water bath, and then } \\
\text { heated to } 60^{\circ} \mathrm{C} \text { during the next } 1.5 \mathrm{~h}\end{array}$ & $\begin{array}{l}0.5 \mathrm{M} \mathrm{H}_{2} \mathrm{SO}_{4}+ \\
0.5 \mathrm{M} \mathrm{HCOOH}\end{array}$ & 187.2 & [14] \\
\hline Pd nanoflowers & $\begin{array}{c}\text { The mixture (PDDA, } \mathrm{HCHO}, \mathrm{K}_{2} \mathrm{PdCl}_{4} \text { ) was heated at } \\
120^{\circ} \mathrm{C} \text { for } 5 \mathrm{~h} \text { by adjusting } \mathrm{pH} \text { value of precursor } \\
\text { solution to } 9.0-10.0 \text { in a Teflon-lined stainless-steel } \\
\text { autoclave }\end{array}$ & $\begin{array}{l}0.5 \mathrm{M} \mathrm{H}_{2} \mathrm{SO}_{4}+ \\
0.5 \mathrm{M} \mathrm{HCOOH}\end{array}$ & 211.3 & {$[15]$} \\
\hline Pd nanochain & $\begin{array}{l}\text { The mixture solution (PDDA, } \mathrm{HCHO}, \mathrm{K}_{2} \mathrm{PdCl}_{4} \text { ) was } \\
\text { transferred to a } 20 \mathrm{~mL} \text { Teflon-lined stainless-steel } \\
\text { autoclave and heated at } 120^{\circ} \mathrm{C} \text { for } 5 \mathrm{~h} \text { by adjusting } \mathrm{pH} \\
\text { value to } 12-13\end{array}$ & $\begin{array}{l}0.5 \mathrm{M} \mathrm{H}_{2} \mathrm{SO}_{4}+ \\
0.5 \mathrm{M} \mathrm{HCOOH}\end{array}$ & 309 & {$[15]$} \\
\hline
\end{tabular}




\section{References}

(1) Lu, K.;Zhang, H.;Gao, S.;Ma, H.;Chen, J.; Cheng, Y. Manipulating Polysulfide Conversion with Strongly Coupled $\mathrm{Fe}_{3} \mathrm{O}_{4}$ and Nitrogen Doped Carbon for Stable and High Capacity Lithium-Sulfur Batteries. Adv. Funct. Mater. 2019, 29, 1807309.

(2) Mjalli, F. S.; Naser, J. Viscosity Model for Choline Chloride-Based Deep Eutectic Solvents. Asia-Pac J. Chem. Eng. 2015, 10, 273-281.

(3) Lin, X.; Terepka, D.; Yang, H. Synthesis of Silver Nanoparticles in a Continuous Flow Tubular Microreactor. Nano Lett. 2004, 4, 2227-2232.

(4) Zhu, C.; Xue, S.; Ikram, R.; Liu, X.; He, M. Experimental Study on Isobaric Molar Heat Capacities of a Deep Eutectic Solvent: Choline Chloride + Ethylene Glycol. J. Chem. Eng. Data 2020, 65, 690-695.

(5) Yan, C.; Rashmi, W.; Khalid, M.; Shahbaz, K.; Gupta, T.; Mas, N. Potential Application of Deep Eutecitc Solvents in Heat Transfer Application. J. Eng. Sci. Tech. 2017, 5, 1-14.

(6) Kashid, M.; Renken, A.; Kiwi-Minske, L. Microstructured Devices for Chemical Process. Weinheim: Wiley-VCH, 2015.

(7) Guo, C. X.; Zhang, L. Y.; Miao, J.; Zhang, J.; Li, C. M., DNA-Functionalized Graphene to Guide Growth of Highly Active Pd Nanocrystals as Efficient Electrocatalyst for Direct Formic Acid Fuel Cells. Adv. Energy Mater. 2013, 3, 167-171.

(8) Zhang, X.; Zhu, J.; Tiwary, C. S.; Ma, Z.; Huang, H.; Zhang, J.; Lu, Z.; Huang, W.; Wu, Y., Palladium nanoparticles supported on nitrogen and sulfur dual-doped graphene as highly active electrocatalysts for formic acid and methanol oxidation. ACS Appl. Mater. Interfaces 2016, 8, 10858-10865.

(9) Qin, Y.-H.; Jia, Y.-B.; Jiang, Y.; Niu, D.-F.; Zhang, X.-S.; Zhou, X.-G.; Niu, L.; Yuan, W.K., Controllable synthesis of carbon nanofiber supported Pd catalyst for formic acid electrooxidation. Int. J. Hydrogen Energy 2012, 37, 7373-7377.

(10) Chen, Y.; Yang, Y.; Fu, G.; Xu, L.; Sun, D.; Lee, J.-M.; Tang, Y., Core-shell CuPd@ Pd tetrahedra with concave structures and Pd-enriched surface boost formic acid oxidation. $J$. Mater. Chem. A 2018, 6, 10632-10638.

(11) Zhang, Y.; Wang, M.; Zhu, E.; Zheng, Y.; Huang, Y.; Huang, X., Seedless growth of 
palladium nanocrystals with tunable structures: from tetrahedra to nanosheets. Nano Lett. 2015, 15, 7519-7525.

(12) Zhang, G.; Zhang, L.; Shen, L.; Chen, Y.; Zhou, Y.; Tang, Y.; Lu, T., Synthesis and electrocatalytic properties of palladium network nanostructures. ChemPlusChem 2012, 77, 936-940.

(13) Bai, Z.; Guo, Y.; Yang, L.; Li, L.; Li, W.; Xu, P.; Hu, C.; Wang, K., Highly dispersed Pd nanoparticles supported on 1, 10-phenanthroline-functionalized multi-walled carbon nanotubes for electrooxidation of formic acid. J. Power Sources 2011, 196, 6232-6237.

(14) Bai, J.; Shen, L.; Sun, D.; Tang, Y.; Lu, T., Facile synthesis and electrocatalytic properties of dendritic palladium nanostructures. CrystEngComm 2014, 16, 10445-10450.

(15) Qiu, X.; Zhang, H.; Wu, P.; Zhang, F.; Wei, S.; Sun, D.; Xu, L.; Tang, Y., One-pot synthesis of freestanding porous palladium nanosheets as highly efficient electrocatalysts for formic acid oxidation. Adv. Funct. Mater. 2017, 27, 1603852. 